\title{
POSSIBILITY USING THERMOGRAPHIC CONTROL METHOD TO DETECT CRACKS IN REINFORCED CONCRETE STRUCTURES
}

\author{
${ }^{1}$ Klymenko Ye.V., Doctor of Engineering Science, Professor, \\ klimenkoew57@gmail.com, ORCID: 0000-0002-4502-8504 \\ ${ }^{2}$ Kolesnichenko S.V., Doctor of Engineering Science, Associate Professor, \\ svk.mk15@gmail.com, ORCID: 0000-0001-5087-8354 \\ ${ }^{2}$ Polianskyi K.V., PhD, Senior teacher, \\ kostyapolyanski@gmail.com, ORCID: 0000-0002-2615-3975 \\ ${ }^{1}$ Popadenko A. O., postgraduate, \\ popadenko@donnaba.edu.ua, ORCID: 0000-0002-5615-7117 \\ ${ }^{1}$ Odessa State Academy of Civil Engineering and Architecture \\ ${ }^{2}$ Donbas National Academy of Civil Engineering and Architecture
}

\begin{abstract}
The article presents the study results of the possibility of using thermographic nondestructive testing to search for cracks in reinforced concrete structures. The basis of nondestructive thermal control is the registration of changes in the thermal field that occurs when the thermodynamic equilibrium of object with the environment is disturbed, which appears on the surface, and the nature of which allows obtaining the necessary information. The thermal control method is based on the interaction of the object's thermal field with thermodynamic sensitive elements (thermocouple, photodetector, liquid crystal element, bolometer), which convert the field parameters (intensity, temperature gradient, contrast, radiance) into an electrical signal of the recording device. As a result of the experiment, it was confirmed that the thermographic control method can be used when examining reinforced concrete structures for a qualitative assessment of hidden defects and damages. Thermal imagers with different resolution of the IR image matrix, an infrared thermo hygrometer, and a luxmeter were used as measuring instruments for the experiment. During the experiment, no fundamental difference in the use of thermal imagers with different types of IR matrices was revealed. When using the more accurate Flir E8 thermal imager, the thermogram had a clearer definition of the surface temperature compared to the Flir C2. This feature can be useful for quantifying defects, for example, the depth and size of a crack under a layer of paint, but fundamentally, for high-quality detection of defects and damage, the use of more accurate equipment is not a prerequisite. The authors conclude that the method of thermographic control can be used when examining reinforced concrete structures for a qualitative assessment of the presence of cracks.
\end{abstract}

Keywords: reinforced concrete structures, crack, thermography, infrared camera, nondestructive testing.

Introduction. The issue of compliance with the requirements for the operation of reinforced concrete structures is fundamental to ensure the normal production process and ensure the safety of industrial personnel, especially due to the large percentage of structures operated outside its design resource, which increases the number of man-made accidents [1].

The accident of buildings caused by reinforced concrete structures is associated with many factors, but is almost always due to the formation of damage in the elements of these structures.

According to the normative documentation [2], the technical condition of individual building structures is characterized by one of four categories: "1" - normal; "2" - satisfactory; "3" - not suitable for normal operation; "4" - emergency. Reinforced concrete structures are characterized by the fact that all of the above categories are characterized by the presence of cracks of different sizes and in different places of structures. From the above we can conclude that cracks are a characteristic defect for reinforced concrete structures.

Bulletin of Odessa State Academy of Civil Engineering and Architecture, 2021, no. 84, page 32-38 
During the technical inspection of reinforced concrete building structures used following methods of non-destructive testing: visual, ultrasonic, radiographic, measuring, electromagnetic, capillary, etc. All these methods allow to solve the problem of detection and determination of parameters of defects and damages, however, as a rule, demand rather labor-consuming works, long technological breaks in production at carrying out control. Also, their use in production conditions is complicated due to the need to meet the requirements for the preparation of structures for inspection, which requires time and significant material costs. Given such limitations as: inability to access the entire surface of the structure, limited number of employees, the impossibility of stationary power supply - a significant area of the structure cannot be inspected.

Non-destructive thermographic control [3] can be used during the production of parts for automatic detection of deviations of geometric parameters of products and the presence of surface defects [4]. To detect defects in steel structures scanning of the surface of the structure heated by a laser beam can be used, the deviation of the shape of the heat point will indicate the presence of a surface defect [5].

Analysis of research and publications. The development of methods and equipment for thermographic control (TC), focused on the diagnosis of the condition and the study of thermophysical characteristics of various materials, is carried out in leading scientific laboratories in the United States and Canada. Germany. France. Finland, Russia, and in recent years India and China.

The first studies on TC were performed in the 70s of last century by Bekeshko N.A., Vavilov V.P., Popov Yu.A., Rapoport D. A., Budadin P. N.,Epiphany B. N. In recent years, the problem of TC is devoted to the study of Abramov E. V., Cheprasova A. H., Zakharenko V. A., Torghunkova V. G.

Most of the attention in the above studies is paid to methods and devices of thermographic control, which are aimed at detecting damage during their occurrence. In particular, in his work Kotelnikov V. V.[6], considers the methods and devices of TC, based on the fact that during the occurrence of deformations in steel structures, under the influence of mechanical stresses, a certain amount of energy (heat) is released, which is fixed by infrared camera. This method of thermal nondestructive testing is called passive and does not allow to detect defects after their formation.

Setting objectives. The basis of non-destructive thermal control is the registration of changes in the thermal field that occurs during the violation of the thermodynamic equilibrium of the object with the environment that appears on the surface, and the nature of which allows to obtain the necessary information. The method of thermal control is based on the interaction of the thermal field of the object with thermodynamic sensitive elements (thermocouple, photodetector, liquid crystal element, bolometer), which convert field parameters (intensity, temperature gradient, contrast, radiance) into an electrical signal of the recording device.

The thermographic method of control uses thermal energy which is distributed in the object of control. The temperature field on the surface is a source of information about the features of the heat transfer process, which, in turn, depend on the presence of internal defects (damage).

There is conditionally passive thermal non-destructive testing (PTNT), active (ATNT) and combined methods of thermographic control [7]. Passive does not require external thermal influence, active, on the contrary, involves heating the object of study with external heat. Combined methods require the additional use of other non-destructive testing methods.

Passive method controls the occurrence of defects and damage during operation and (or) operation of the facility. These are the most common methods used during energy audits, control of live appliances.

The active method is used when during the operation of the facility not enough heat radiation is emitted to perform the survey. In this case, the object is additionally heated by an external heat source [8].

The most common thermal control devices are infrared cameras (thermal imagers). The devices are equipped with infrared sensors (bolometers) and a special digital display, which displays a picture of the thermal field. As a rule, all thermal imagers have special software for processing the received thermograms. There is also a division into supervisory and measuring thermal imagers, but the former do not have wide special use, because, as a rule, the value of the surface temperature of the object is controlled. 
Thermal conductivity - the ability of a substance to transfer thermal energy, as well as a quantitative assessment of this ability: a physical quantity that characterizes the intensity of heat transfer in a substance, which is equal to the ratio of heat flux density to temperature gradient. The phenomenon of thermal conductivity is that kinetic energy atoms and molecules which determines temperature body, transmitted to atoms and molecules in those areas of the body where the temperature is lower.

In the heated region of matter there are more electrons with high energy, they easily migrate to colder regions, and lose energy there, scattering on oscillations. crystal lattice.

In structurally homogeneous bodies, the distribution of heat by thermal conductivity (thermal gradient) occurs evenly in all directions from the hottest point, in the case when the body has structural inhomogeneities or damage (e.g. crack), there is a noticeable "stepwise" thermal gradient time of thermal imaging examination [9].

ATNT can also be divided into control during heating and control during cooling. ATNT during heating should be used to detect areas of inhomogeneity in mostly homogeneous bodies, ATNK during cooling allows to detect foreign inclusions (for example, areas of corrosion, when instead of metal there is its oxide), to control welds because the weld material differs from the material structure, it cools at a different (relative to the material of construction) speed.

The aim of the study is to experimentally determine the possibility and effectiveness of the use of ATNT to search for and identify visually indeterminate cracks in steel structures.

Research methodology. FLIR C2 thermal imagers with an IR image resolution (thermal image) of $80 \times 60$ pixels and FLIR E8 with an IR image matrix resolution of $320 \times 240$ pixels, infrared thermo hygrometer, luxmeter were used as measuring devices for the experiment.

Tasks of experimental research included:

1. Exploring the possibilities of the basic application of the thermographic control method for the inspection of reinforced concrete structures.

2. Search for solutions to possible problems with devices.

3. Development of methods of works performance at carrying out inspections by a method of thermographic control taking into account a real condition of designs.

For the experiment as an object of study was used a sample of reinforced concrete structure in the form of a reinforced concrete flat slab with dimensions of $1200 \times 400 \times 50 \mathrm{~mm}$ (Fig. 1) on which there are cracks after impact.

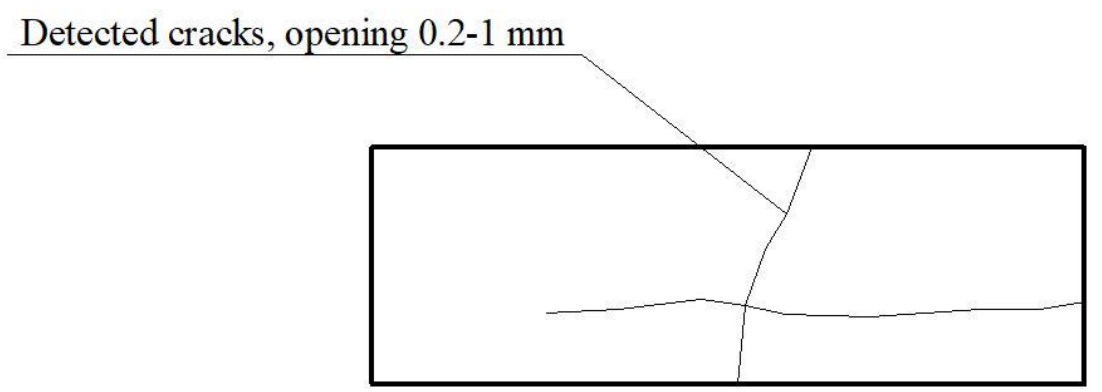

Fig. 1. Schematic representation of the sample

The research methodology included the following basic operations:

1. Examination and preliminary assessment of a sample having defects and damage, the determination of which by visual method is difficult or impossible.

2. Determination of climatic parameters of the study area (temperature, relative humidity, natural light).

3. Heating the samples to a temperature $\approx 100^{\circ} \mathrm{C}$.

4. Scanning and recording of thermograms on infrared cameras Flir C2 and Flir E8 with natural cooling of samples to a temperature $\approx 30^{\circ} \mathrm{C}$.

5. Processing of data from thermograms using the Flir Tools software package.

6. Comparison of data obtained using infrared cameras Flir C2 and Flir E8. 
7. Determination of places of damage on thermograms with formation of samples of thermograms.

Heating of the test sample was performed in different ways: convective heating, radiation heating, contact heating.

Research results. As a result of the experiment, it was confirmed that the thermographic method of control can be used during the inspection of reinforced concrete structures to qualitatively assess the presence of hidden defects and damage. In Fig. 2 shows a photographic (a) and infrared (b) image of the area of the examined sample, the infrared image shows two crossed cracks caused by impact, they look like sharp changes in the thermal field.

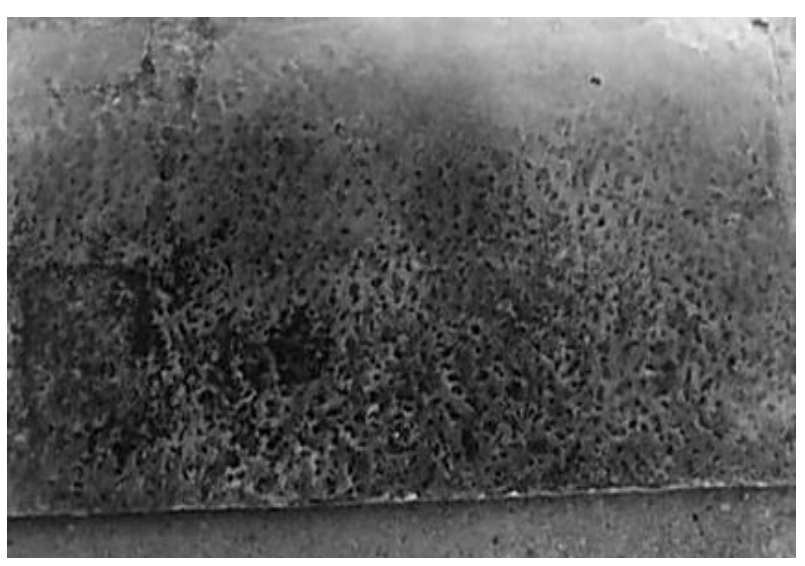

a)

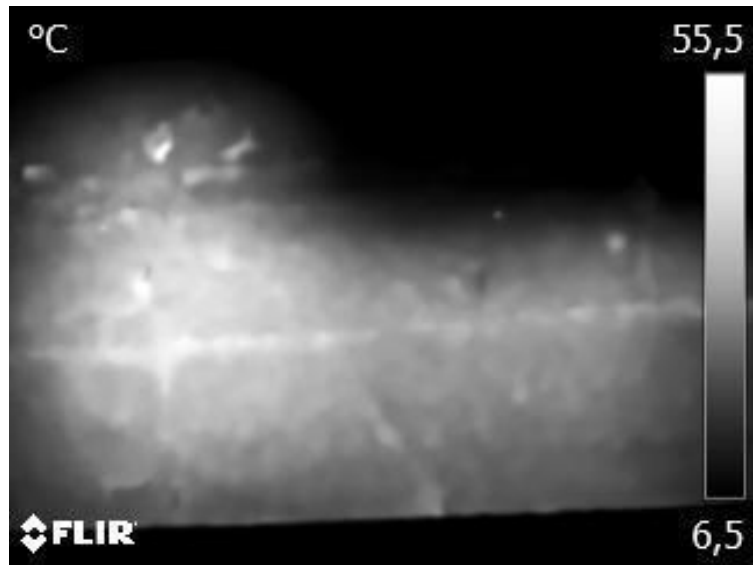

b)

Fig. 2. The image of the area of the examined sample: $a$ - photographic; $b$-infrared

Depending on the size of the opening and the shape, the cracks on the thermograms can look like solid or discontinuous contrasting lines, the larger the opening of the crack, the more contrasting it is on the thermogram.

In Fig. 3 photographic (a) and infrared (b) image of the area of the examined sample with a longitudinal crack opening of $0.7 \mathrm{~mm}$ is shown.

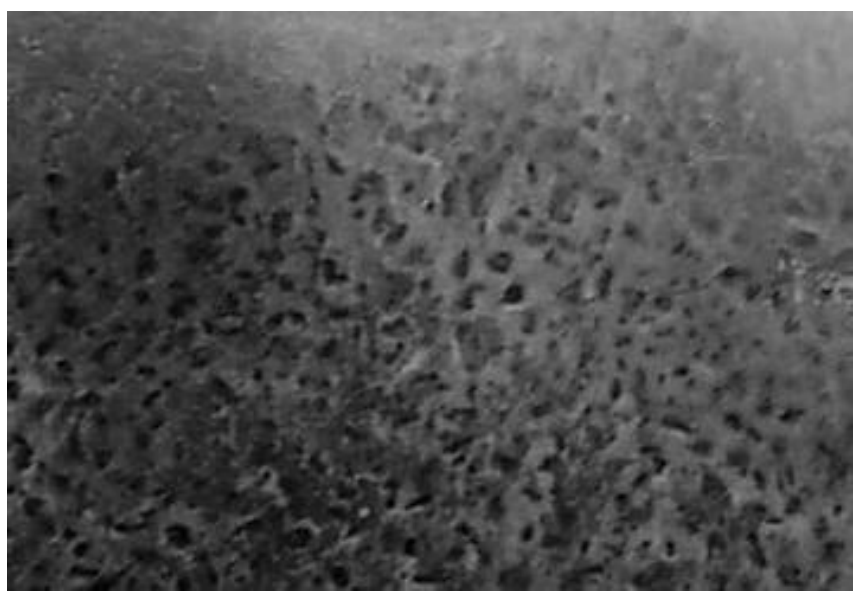

a)

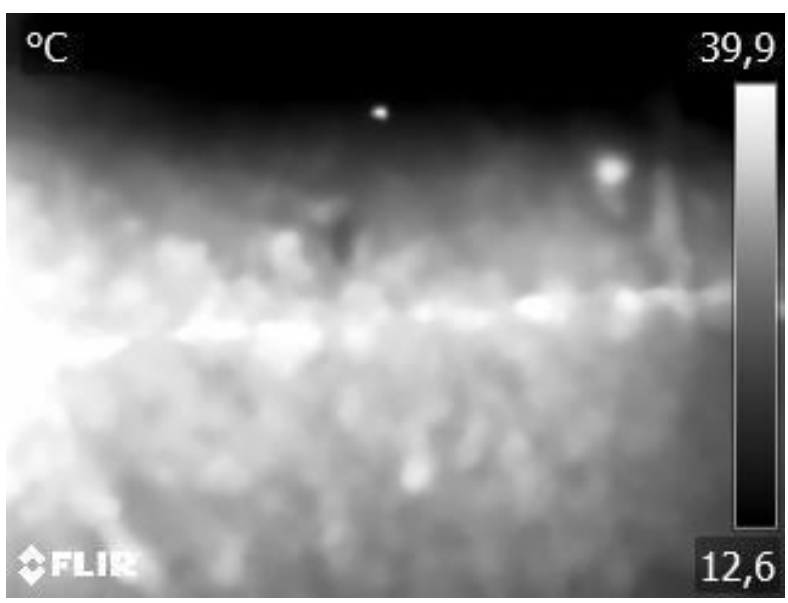

b)

Fig. 3. Image of the area of the examined sample with a longitudinal crack opening $0.7 \mathrm{~mm}$ : $a$ - photographic; $b$ - infrared

Fig. 4 shows a photographic (a) and infrared (b) image of the area of the examined sample with transverse and longitudinal cracks opening 0.7-1.0 $\mathrm{mm}$, intersecting. 


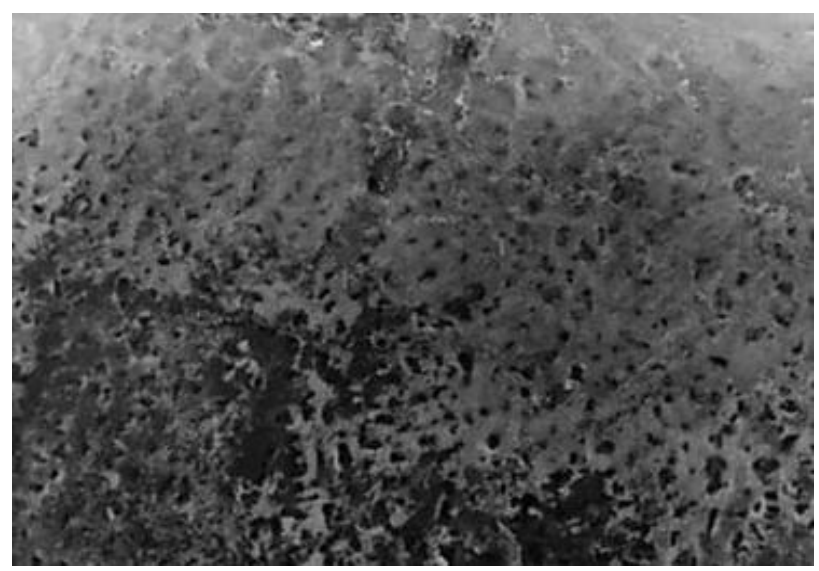

a)

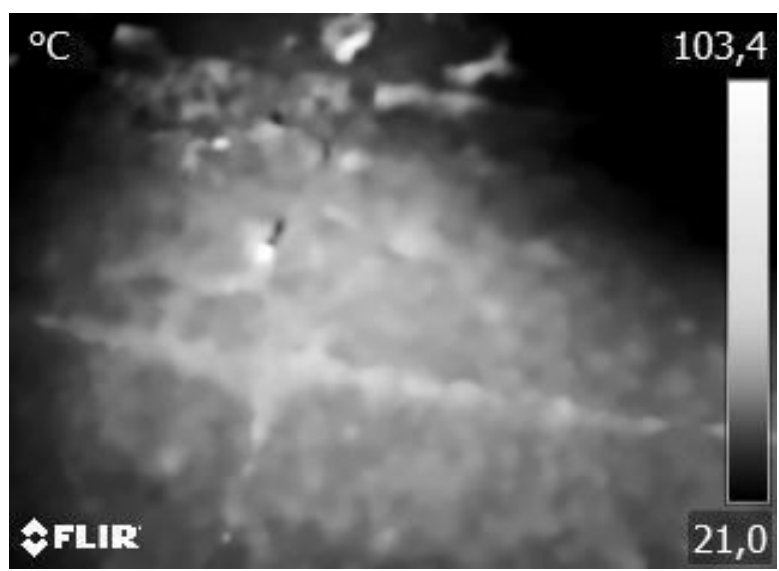

b)

Fig. 4. Image of the area of the examined sample with transverse and longitudinal cracks opening

0.7-1.0: a - photographic; $b$ - infrared

Thus, to obtain reliable data when using the method of active thermography, it is necessary to consider the following parameters:

- ambient air temperature;

- air humidity;

- the angle of inclination of the optical axis of the measuring instrument to the surface of the object under study;

- natural light of the object of study;

- the presence in the field of view of the thermal imager of high-temperature objects.

Conclusions. The thermal control method does not require high-precision infrared equipment. During the experiment, no fundamental difference in the use of thermal imagers with different types of IR arrays was found. When using a more accurate Flir E8 thermal imager, the thermogram had a clearer definition of the surface temperature compared to the Flir C2. This feature can be useful for quantifying defects - for example, the depth and size of the crack under the paint layer, but in principle, for a qualitative finding of defects and damage, the use of more accurate equipment is not mandatory.

Infrared and contact heating proved to be the best heating methods because they allow to accurately locate the heating zone of the sample.

From the above data it follows that the use of thermal non-destructive testing significantly increases the likelihood of finding locations of dangerous hidden defects and damage and improves the quality of the results of the survey of the technical condition of reinforced concrete structures.

\section{References}

[1] P. Thoft-Christensen, Risk Analysis in Civil Engineering. Aalborg: Dept. of Building Technology and Structural Engineering. Structural Reliability Theory, no. 2 224, vol. R0163, p. 24, 2001.

[2] DSTU-N B V.1.2-18:2016. Nastanova shchodo obstezhennia budivel i sporud dlia vyznachennia ta otsinky tekhnichnoho stanu.Kyiv: 2017.

[3] A. Killey, J.P. Sargent, "Analysis of thermal nondestructive testing", 22 (1): 216, 2000.

[4] Beate Oswald-Tranta, Paul O'Leary, "Fusion of geometric and thermographic data for automated defect detection", Journal of Electronic Imaging, 21 (2): 1108. 2012.

[5] S. Kolesnichenko, A. Popadenko, Y. Selyutyn, "Detection of Dangerous Defects and Damages of Steel Building Structures by Active Thermography", Materials Science Forum - Trans Tech Publications Ltd, Switzerland, vol. 1038 -539, pp. 417-423, 2021.

[6] V.V. Kotelnikov, «Razrabotka metodyky teplovoho kontrolia y dyahnostyky tekhnycheskoho sostoianyia metallokonstruktsyi mostovikh kranov», dis. ... k-ta tekhn. nauk: Bauman MSU. Moscow, 2009. 
[7] Europian Standart EN 16714-1. Non-destructive testing - Thermographic testing. Part 1: General principles. CEN, Brussels, 2016.

[8] M. Belkacemi, C. Stolz, A. Mathieu, G. Lemaître, J. Massich, and O. Aubreton, "Nondestructive testing based on a scanning-from-heating approach: Application to nonthrough defect detection and fiber orientation assessment", Journal of Electronic Imaging, 24 (6): 061112, 2015.

[9] A. Popadenko, S. Kolesnichenko, "Shchodo mozhlyvosti vykorystannia termohrafichnoho sposobu kontroliu dlia vyiavlennia trishchyn u stalevykh konstruktsiiakh", Suchasni budivelni konstruktsii z metalu ta derevyny, vol. 24, pp. 109-118, 2020.

\title{
ВОЗМОЖНОСТЬ ИСПОЛЬЗОВАНИЯ ТЕРМОГРАФИЧЕСКОГО СПОСОБА КОНТРОЛЯ ДЛЯ ВЫЯВЛЕНИЯ ТРЕЩИН В ЖЕЛЕЗОБЕТОННЫХ КОНСТРУКЦИЯХ
}

\author{
${ }^{1}$ Клименко Е.В., д.т.н., профессор, \\ klimenkoew57@gmail.com, ORCID: 0000-0002-4502-8504 \\ ${ }^{2}$ Колесниченко С.В., д.Т.н., доцент, \\ svk.mk15@gmail.com, ORCID: 0000-0001-5087-8354 \\ ${ }^{2}$ Полянский К.В., доктор философии, ст. преподаватель, \\ kostyapolyanski@gmail.com, ORCID: 0000-0002-2615-3975 \\ ${ }^{1}$ Попаденко А.О., аспирант, \\ popadenko@donnaba.edu.ua, ORCID: 0000-0002-5615-7117 \\ ${ }^{1}$ Одесская государственная академия строительства и архитектуры \\ ${ }^{2}$ Донбасская национальная академия строительства и архитектуры
}

\begin{abstract}
Аннотация. В статье приведены результаты исследования возможности использования термографического неразрушающего контроля для поиска трещин в железобетонных конструкциях. Основой неразрушающего теплового контроля является регистрация изменений теплового поля, возникающего при нарушении термодинамического равновесия объекта с окружающей средой, которое появляется на поверхности, и характер которого позволяет получить необходимую информацию. Метод теплового контроля базируется на взаимодействии теплового поля объекта с термодинамическими чувствительными элементами (термопара, фотоприёмник, жидкокристаллический элемент, болометр), которые преобразуют параметры поля (интенсивность, температурный градиент, контрастность, лучистость) в электрический сигнал регистрирующего устройства. В результате проведения эксперимента было подтверждено, что термографический способ контроля может быть использован при обследовании железобетонных конструкций для качественной оценки скрытых дефектов и повреждений. В качестве измерительных приборов для проведения эксперимента использовались тепловизоры с различной разрешающей способностью матрицы ИК изображения, инфракрасный термогигрометр, люксметр. Во время проведения эксперимента не было выявлено принципиальной разницы применения тепловизоров с различными типами ИК матриц. При использовании более точного тепловизора Flir E8 теплограмма имела более четкое определение температуры поверхности по сравнению с Flir С2. Эта особенность может пригодиться для количественного определения дефектов, к примеру, глубины и размеров трещины под слоем краски, но принципиально, для качественного обнаружения дефектов и повреждений, использование более точного оборудования не является обязательным условием. Авторы делают выводы о том, что способ термографического контроля может быть использован при обследовании железобетонных конструкций для качественной оценки наличия трещин.
\end{abstract}

Ключевые слова: железобетонные конструкции, трещина, термография, инфракрасная камера, неразрушающий контроль. 


\title{
ЩОДО МОЖЛИВОСТІ ВИКОРИСТАННЯ ТЕРМОГРАФІЧНОГО СПОСОБУ КОНТРОЛЮ ДЛЯ ВИЯВЛЕННЯ ТРІЩИН У ЗАЛІЗОБЕТОННИХ КОНСТРУКЦІЯХ
}

\author{
${ }^{1}$ Клименко Є.В., д.Т.н., професор, \\ klimenkoew57@gmail.com, ORCID: 0000-0002-4502-8504 \\ ${ }^{2}$ Колесніченко С.В., д.т.н., доцент, \\ svk.mk15@gmail.com, ORCID: 0000-0001-5087-8354 \\ ${ }^{2}$ Полянський К.В., доктор філософії, ст. викладач, \\ kostyapolyanski@gmail.com, ORCID: 0000-0002-2615-3975 \\ ${ }^{1}$ Попаденко А.О., аспірант, \\ popadenko@donnaba.edu.ua, ORCID: 0000-0002-5615-7117 \\ ${ }^{1}$ Одеська державна академія будівництвва та архітектури \\ ${ }^{2}$ Донбаська національна академія будівництва і архітектури
}

\begin{abstract}
Анотація. У статті наведено результати дослідження можливості використання термографічного неруйнівного контролю для пошуку тріщин в залізобетонних конструкціях. Основою неруйнівного теплового контролю $є$ реєстрація змін теплового поля, що виникає при порушенні термодинамічної рівноваги об'єкта 3 навколишнім середовищем, яке з'являється на поверхні, і характер якого дозволяє отримати необхідну інформацію. Метод теплового контролю базується на взаємодії теплового поля об'єкта 3 термодинамічними чутливими елементами (термопара, фотоприймач, рідкокристалічний елемент, болометр), які перетворюють параметри поля (інтенсивність, температурний градієнт, контрастність, променистість) в електричний сигнал реєструючого пристрою. В результаті проведення експерименту було підтверджено, що термографічний спосіб контролю може бути використаний при обстеженні залізобетонних конструкцій для якісної оцінки прихованих дефектів і пошкоджень. В якості вимірювальних приладів для проведення експерименту використовувалися тепловізори 3 різною роздільною здатністю матриці ІЧ зображення, інфрачервоний термогігрометр, люксметр. Під час проведення експерименту не було виявлено принципової різниці застосування тепловізорів з різними типами ІЧ матриць. При використанні більш точного тепловізора Flir E8 термограма мала більш чітке визначення температури поверхні в порівнянні 3 Flir C2. Ця особливість може стати в нагоді для кількісного визначення дефектів, наприклад, глибини і розмірів тріщини під шаром фарби, але принципово, для якісного виявлення дефектів і пошкоджень, використання більш точного обладнання не є обов'язковою умовою. Автори роблять висновки про те, що спосіб термографічного контролю може бути використаний при обстеженні залізобетонних конструкцій для якісної оцінки наявності тріщин.

Ключові слова: залізобетонні конструкції, тріщина, термографія, інфрачервона камера, неруйнівний контроль.
\end{abstract}

Стаття надійшла до редакції 3.09.2021 